\title{
The Construction and Research of the Training Mode and the Mixed Teaching Method of Mechanical Engineering Specialty Based on the Achievement-oriented Education
}

\author{
Shuang Zhang ${ }^{1, a}$, Xiangyan Lv ${ }^{1, b}$ \\ ${ }^{1}$ School of mechanical, Beihua University, Jilin 132021, China \\ a38011541@qq.com,*Corresponding authorEmail: ${ }^{b} 12283894 @ q q . c o m$
}

Keywords: achievement-oriented, machinery, industrial engineering, personnel training, teaching method.

\begin{abstract}
As an advanced education concept in the present time, the result-oriented education concept has been widely accepted in developed countries such as the United States and Canada, and is an important part of the development of education concept in the international community. The introduction and implementation of the achievement-oriented education concept is beneficial not only to the cultivation of engineering talents, but also to the cultivation of talents in domestic institutions of higher learning and education reform. This paper will focus on the idea of achievement-oriented education, and discuss the training mode of mechanical industrial engineering talents from the aspects of curriculum setting, teaching method and practice.
\end{abstract}

Modern industry and the development of science and technology in the liberation of labor, the development of productivity greatly at the same time, also for the workers engaging in the production ability and quality put forward higher requirements, results oriented education concept in the United States and other developed countries have played an important role in education reform, for our country's personnel training and teaching management in colleges and universities has important inspiration significance. Education concept guides based on the results of mechanical industrial engineering personnel training mode, to accurately understanding results oriented education concept connotation, and, starting from the cultivation idea, scheme and so on many aspects of into education in colleges and universities teaching management practice, in the final goal of education of talent training on the implementation of more scientific and more productive.

\section{Achievement-oriented Education Concept and its Connotation}

The so-called results-oriented Education Education, whose basic concept is to emphasize the achievements made by students after receiving Education, takes the learning results of students as the starting point and goal of teaching work, and makes adjustment and scheduling of teaching objectives, teaching design and teaching plans. Since the concept of results-oriented education was put forward 
in the 1980s, this concept of education has been widely recognized and popularized, especially for mechanical engineering and other practical majors. The implementation of the idea of results-oriented education has achieved good results in talent cultivation.

Results oriented education concept in the pursuit of students received the maximization of personal ability can be obtained after education, "results" by income, education in the education idea, the main emphasis is "what is want to let the students learning results, and why, and know how to effectively help the students achieve the learning outcomes" four problems, such as. The personnel trained by mechanical engineering specialty should not only have solid theoretical knowledge, but also have certain management ability. It is necessary not only to have excellent professional quality in mechanical design and machining, but also to be able to master and play an effective role in computer application and resource scheduling. The purpose of cultivating industrial engineering professionals is to effectively improve the utilization rate of resources, reduce cost and time consumption in the process of enterprise production and social development, so as to promote the comprehensive development of modern industry.

\section{Study on the Training Mode of Mechanical Engineering Professionals Based on Achievement-oriented Education}

The traditional mode adopted by colleges and universities in the training of mechanical professionals is subject-oriented, and the content that students should master is standardized through course setting and taken as the assessment standard, which usually runs counter to the actual production of enterprises. Only through work results or achievements can we consider the strength and weakness of personnel training. Based on the education concept of results-oriented, personnel training in mechanical industrial engineering can be conducted from the following aspects.

\subsection{Change the Teaching Philosophy and Optimize the Curriculum}

As a professional talent in mechanical engineering, the standard is to master solid basic knowledge of mechanical engineering, such as mathematics and mechanics, not only engineering economics and engineering principles, but also production planning and control and design planning. At the same time, modern industrial engineering professionals also need to have extensive knowledge, and should be familiar with social science, humanities, engineering mathematics, management engineering foundation, etc., so the school must include these education contents into students' learning objectives and tasks. Machinery industrial engineering talents cultivation is not only an important task of school teaching, and is the inevitable demand of modern social and economic development, the personnel engaged in the work of mechanical engineering in the future must be a compound talents with high skills, high quality, and put forward of the concept of "industrial engineering" is both to have engineering and technical aspects of the professional knowledge and scientific management of basic literacy, is the integration of natural science and social science. Based on the idea of result-oriented education, the training of mechanical industrial engineering professionals should be carried out comprehensively. The future employment direction and market demand of mechanical majors should be fully considered, the position of theoretical and practical courses should be well taught, professional skills should be well taught, and comprehensive qualities should be cultivated.If you follow the "checklist" your paper will conform to the requirements of the publisher and facilitate a problem-free publication process. 


\subsection{Establish a Sound Tracking and Evaluation System for Achievement-oriented education}

Results oriented education concept should be highlighted how much students have mastered skills of the control, emphasizes the education after can have achievement, to better "results" to promote the development of education and teaching work, to gradually establish and perfect the late on student learning outcomes of tracking and evaluation system, fully understand and grasp the student to the learning outcomes achieved. Under the guidance of results-oriented education, attention should be paid to the position of target achievement, and a perfect learning result tracking and evaluation system should be established, which coincides with the demand for interdisciplinary talents in mechanical engineering specialty. Learning outcomes, tracking and evaluation that is the school in the teaching plan and teaching plan "should build a learning achievement evaluation system, the system to evaluate the teaching effect so as to promote cultivation program, teaching contents, teaching methods and the continuous improvement of the quality of teaching", this kind of education is not only the evaluation of teaching ideas and teaching practice, and to provide better results oriented education concept teaching, is an important means of guarantee results orientation can play a role.

\subsection{Professional Skills Training and Practice Based on School-enterprise Cooperation}

The training goal for industrial engineering professionals is to have the basic application ability of technology such as mechanical design and mechanical manufacturing, and professional skills and business ability should be the basic index of leading "achievements". In order to strengthen students' practical practice and professional business ability, adopting school-enterprise cooperation talent cultivation is an important measure to implement education and achieve the expected goal in the current stage, as well as the practical need and future orientation of enterprise development. "From the professional personnel training mode innovation and high-quality" double type "teachers team construction, etc, to explore and practice, in order to improve the students' engineering consciousness, engineering quality and engineering application ability, cultivating application-oriented mechanical, realizes the university fosters the talent and the seamless joint between demand", students' achievements inspection broke the previous examination paper examination test, pay more attention to the time the inspection standards, science and technology to give priority to with practical test results gained by the students, supported by practice, the enterprise production innovation need to inject fresh blood, university-enterprise cooperation mode of talent training to adapt to the demand of the enterprise, It is easy to get the support of the cooperative enterprise. From these two aspects, school-enterprise cooperation is a good choice for both the demand of the university and the demand of the enterprise. What's more, for students majoring in industrial engineering, both academic study and vocational competitiveness are beneficial.

\subsection{Personnel Training under the Development of Modern Information Technology}

Based on the idea of results-oriented education, the company aims to cultivate mechanical industrial engineering talents comprehensively. It should combine the training of mechanical industrial engineering talents with the current rapid development of computer technology. Digital, intelligent, high science and technology is the irreversible development trend, "Internet +" strategy implementation, mechanical design, mechanical processing and other projects in the homework is inseparable from the computer information technology support, in the process of talent training as its key cultivation objectives and, to be able to make full use of the computer information technology 
and operations research, surveying and other machinery industrial engineering related disciplines in computer information technology driven development.

\section{Conclusion}

With advanced results oriented education concept as the guidance, in the cultivation of the engineering machinery industry professionals work do a good job in the curriculum and teaching design, pay attention to students' learning situation track feedback, at the same time through the university-enterprise cooperation in a variety of ways to strengthen the training of practical skills of engineering talent, rich content, the innovation form, can really develop service production, service society of industrial engineering professionals, for the development of machinery industry in China provide a powerful driving force

\section{Acknowledgments}

Research project of education teaching reform of north China university, 2017 university-level general topic, project name: research on heuristic and participatory teaching methods of industrial engineering major, project approval number :XJYB2017008;

Research project of education teaching reform of north China university, 2017 university-level key project, project name: research and practice of university curriculum assessment under the mixed teaching mode, project approval number :XJZD2017037;

The 2017 general planning project of education scientific "13th five-year plan" 2017 in jilin province, project name: research on the training mode of mechanical industrial engineering professionals based on the idea of education guided by OBE achievements, project approval number :GH170118;

Social science research project of "13th five-year plan" of education department of jilin province, project name: study on education model of entrepreneurship and construction of teaching system of local colleges and universities, jieshua zi [2016] no. 48.

\section{References}

[1] Li zhiyi, Zhu hong, Liu zhijun et al. guided education teaching reform of higher engineering with the idea of result-oriented education [J]. Education research of advanced engineering, 2014(2):29-34.

[2] Jia Bing, Chen xiaodong, Li he, etc. Construction and practice of evaluation system of professional learning achievements under the concept of OBE -- a case study of social work in Shenyang University of chemical technology [J]. Science and education guide, 2017(3z):42-43.

[3] Chen zhigang, Wu haijiang, Yuan wenhua, etc. Research and practice on the training mode of mechanical applied talents based on school-enterprise cooperation [J]. Light industry technology, 2015 (8):150-151. 